\title{
Reading Pictures: Piranesi and Carceral Landscapes
}

\author{
Eamonn Carrabine \\ University of Essex
}

Giovanni Battista Piranesi's disturbing images of fantasy prisons set out in his Carceri d'Invenzione, published in the middle decades of the eighteenth century, have had a profound impact on cultural sensibilities. In his own day, Piranesi had achieved acclaim for his images of the decaying architecture of ancient Rome and it was the scale of this 'melancholy dilapidation' (Scott, 1975:20) that also informed the awesome imagery contained in the Carceri. The chapter explores Piranesi's distinctive visual language and situates it in an eighteenth century penchant for ruins and what they might signify. The macabre fantasy structures bear little relation to actual, existing prison buildings, but they do herald a new aesthetic combining both terror and beauty to sublime effect. This chapter is the latest step in my ongoing effort to indicate how punishment has an art history and the project is one tracing forms of representation from the 1500s up to the present day (Carrabine, 2016, 2018a, 2018b). In this regard Piranesi's art is pivotal and his disturbing compositions demand detailed analysis, as they offer insight into the rich complexity of the relation between past and present.

The overall ambition is to indicate how punishment has an art history and by studying it as such the suggestion is that the gap between the disciplines might be bridged. It is driven by the premise that the history of punishment and the history of art are linked in ways that have yet to be fully recognized. For instance, studying the visual culture of punishment is a way of recovering a body of thought about how the poor 'saw' in eighteenth-century Britain, not least since one of the many slang terms for the gallows was the 'the sheriff's picture frame' (Gamer, 2015). Just under two decades ago it could be claimed that 'visual representations. . . have been largely ignored in the social sciences', which is indicative of a 'deep mistrust' of images (Holliday, 2000:503-4) in disciplines like anthropology, economics, geography and sociology, where the uses of visual material in social research has long been marginalised. Yet since then there has been a striking resurgence of interest in visual methods across the social sciences, which has been accompanied by a rise in scholarship on visual culture that has now established itself as an exciting and expanding intellectual field.

Visual criminology is one instance of this development (see Brown and Carrabine, 2017, for a range of examples and McClanahan, 2019, for an account of the ways that rurality has been imagined and visualized as a landscape of horror), but the challenge remains one of constructing a framework that can do justice to both the power of images in social life and their place in social research. It is possible to see a distinctive form of "visual narrative analysis' developing and covering a broad range of approaches: where some social scientists 'tell a story with images, others tell a story about images that themselves tell a story' (Riessman, 2008:140-1, emphasis in original). In this chapter I will be concentrating on the latter, but it is important to recognise the tensions between 'word' and 'image', where the word is associated with 'law, literacy, and the rule of elites', while the image is equated "with popular superstition, illiteracy, and licentiousness" (Mitchell 2015:13). Especially since they are long standing and concern a certain privileging of textual narrative over visual description, even in disciplines like art history where one would expect this not to be so. I begin by setting out these deep seated tensions in a little more detail, as both visual and 
narrative approaches in criminology are still in their infancy and have much to learn from these disputes.

\section{Image and Narrative}

In his introduction to a ground breaking collection of essays on art by leading French thinkers (including Barthes, Baudrillard, Foucault, Kristeva and Serres) Norman Bryson makes the point that so much anglo-american art history 'reacts to the image by seeking documentation: that is where it does its reading - in documents" and he occasionally has the "sense that patronage studies, in particular, will read anything rather than read the painting' (1988:xvi, emphasis in original). The collection was explicitly designed to address this audience and highlighted the importance of reading a painting as a semiotic sign and opened up this world to the then contemporary currents in 'critical theory', which had become the umbrella term to cover feminism, Marxism, psychoanalysis, postcolonialism and poststructuralism. This movement transformed art history as an academic discipline and was foundational to the 'new' art history that had begun to invade and challenge the tranquil domains of the visual arts. Scholars from various disciplines, most notably from literary studies and philosophy, have migrated to the field and revitalized art history, suggesting there is much to be gained from pursuing interdisciplinary strategies and crossing disciplinary borders.

The relationships between 'art history' and 'history' are also telling, and much can be gleaned from Hayden White's humorous intervention at a conference in the late 1980s, where he reportedly "chided art historians with tongue-in-cheek comments about his "coming from the side of campus where real history is taught", which he distinguished from the "slide shows to young men and women ripe for a European tour"' (in Harris, 2001:22, emphasis in original). This kind of scepticism toward art history's procedures as a form of historical inquiry was certainly significant in the critique of the discipline mounted from other radical quarters. White is an influential historian and his Metahistory (1973) provided a narrative analysis of classic historical texts, focussing on such nineteenth century luminaries as Jules Michelet, Leopold Ranke, Alexis de Tocqueville and Jacob Burkhardt. He maintained that each modelled his narrative (or 'emplotted' to use White's own term) on a distinct literary genre - Michelet wrote his histories in the form of romance, Ranke in that of comedy, Tocqueville deployed tragedy and satire prevails in Burkhardt. Of course, this also the poses the question of what is 'real' history and it has been said that White's own position sits on the border between two propositions: "the conventional view that historians construct their texts and interpretations, and the unconventional view that they construct the past itself' (Burke, 2008:83).

The chapter examines the relationships between narrative and visual methods by considering that scholarship in art history which has sought to address the relationships between 'word' and 'image'. Much of it belongs to the 'new art history' in the 1980s, and which had become critical of how conventional approaches in the discipline had tended to see art as the visualisation of narrative. For example, Bryson's (1981) study of French painting in the Ancien Régime explored the relationships between 'word' and 'image' by examining the kind of stories pictures tell, drawing a distinction between the 'discursive' aspects of an image (posing questions on visual art's language-like qualities and relationships to written text) and those 'figural' features that place the image as primarily a visual experience - it's 'being-asimage' - that is entirely independent of language. The tension between words and images was later explored by Mieke Bal (1991) in her Reading "Rembrandt" where she strives to 
reconcile a semiotics of visual art with a 'narratology' of it, drawing on her background in literary studies she studied the interplay of verbal and visual elements to understand the role of narrative in pictures. In particular, she examines how a still image tells a dynamic story unfolding in time, identifying 'how textuality determines the rhetorical effect of paintings' (Bal, 1991:31).

Svetlana Alpers, in contrast, situates herself much more explicitly in opposition to the 'old art history' and its iconographic methods. Her Art of Describing (1983) insists that Italian Renaissance art, which preoccupied much of the writing of art history is invested in narrative, while seventeenth century Dutch art was concerned rather with 'picturing'. Dutch painting depicts or reconstructs, the process of seeing itself, as a central function of a visual culture where meaning is not so much 'read', but is instead 'seen'. While her essay 'Interpretation without Representation, or, The Viewing of Las Meninas' (1983/1995) takes Foucault's extraordinary reading of the enigmatic painting by the Spanish artist Velasquez, which completely bypassed art historical methods altogether in his discourse analysis of the picture, as the basis for articulating her own discontent with traditional art history methods. She acknowledges the strength of his analysis, which is carefully attuned to pictorial surface and his ambition to 'keep the relation of language to vision open' (Foucault, 1966/2002:10). Foucault focused on the artwork itself, as if it were before him and described in meticulous detail what he saw to prompt questions about the nature of representation itself. His analysis highlights how the picture works as a discourse by describing how the complex arrangement of visual exchanges in it speaks to various subject positions in complex and uncertain ways. It depicts Velasquez in the act of creating a portrait of Philip IV and his second wife Mariá Anna by placing the viewer in the positions that the sitters would have occupied - and they are shown only reflected in a distant mirror at the back of the painting - so that the spectator becomes Sovereign. The significance of the painting, Foucault maintains, rests in its selfreflexive awareness of what it means to represent the world.

It is here that Alpers suggests that the strength of Foucault's interpretation lies, as she goes on to argue that the picture oscillates between two contrasting modes of representation that are central to Western art. One mode, typically Italian, treats painting as like 'a window on the perceived world', where the artist and the viewer look from the 'same side of the picture surface' though the use of linear perspective, while the second mode 'is not a window but rather a surface onto which an image of the world casts itself' and is more Dutch, detached and descriptive (Alpers, 1983/1995:288-9). It treats the painterly surface as a fragment of the world, with no regard to human scale or viewer. The power of Las Meninas, Alpers argues, inheres in its dazzling embrace of these conflicting tactics of representation. This conclusion could not be reached through the then conventional art history methods, which have sought meaning through narrative plot, rather than close attention to visual representation. The force of her critique then resides in the need to see what is actually before our eyes, rather than rely purely on texts, to address 'fundamental questions about the nature of representation, meaning and interpretation' (Greslé, 2006:227).

These remain important arguments and they indicate that one of the defining features of the 'new' art history was an 'interest in image/text relations' (Harris, 2001:175), which have considerable importance as visual and narrative criminologies take shape. The focus on language is symptomatic of the 'linguistic turn' that has had such a profound influence on intellectual thought since the 1960s and this chapter will concentrates on one strand in it. In particular, it will introduce the approach Jacques Derrida developed and defined as 
'deconstruction', which in some important respects revealed the limitations of language, and seeks to create the effects of 'decentring' by highlighting how signification is a complex, often duplicitous, process. The chapter then situates Piranesi's images in an account of landscape, not least since he was a leading exponent of the veduta (a faithful representation of an actual urban or rural view) that had achieved the status of a distinctive and popular genre by the eighteenth century. Yet it was only really from the 1500s that the first independent landscapes in the history of European art began to appear, and it is here we begin.

\section{The Origins of Landscape}

The emergence of landscape as a distinct, independent genre occurred during the sixteenth century and offered densely textured depictions of that quintessentially German place - the forest. In eerie scenes that create a mood of disorder these radical experiments in representation wrestled landscape away from its subsidiary role as pictorial setting for biblical or historical subjects. These were remarkable pictures that told 'no stories', mostly devoid of living creatures, human or animal, but 'which nevertheless make a powerful impression of incompleteness and silence' (Wood, 1993/2014:9). Crucially, they originated in northern Europe, where the relationship of landscape place-setting to narrative storytelling was frequently different from the artistic output associated with the Italian Renaissance and particularly in Florence, Venice and Rome. Of course, there are some astonishing and complex landscape vistas in the great works from the period, but with only a handful of controversial exceptions do empty landscapes (that is without a human or religious subject) appear in finished, formal paintings. Nor do they yet exist as an independent, full-fledged genre. According to Christopher Wood (1993/2014) the origins of the tradition can be traced to the German painter Albrecht Altdorfer (c.1480-1538), a contemporary of Lucas Cranach and leading light of the Danube School of painters. Altdorfer's innovation was to prise 'landscape out of a merely supplementary relationship to subject matter' (Wood, 1993/2014:41) and nothing like his enigmatic landscape paintings would be seen again until the end of the sixteenth century.

Wood's use of the term 'supplementary' here is deliberately designed to invoke Jacques Derrida's understanding of the 'supplement' to a work. Although Derrida mainly concentrated on philosophical and literary texts, he also deconstructed works of art - most notably in his The Truth in Painting (Derrida, 1978) to explore the importance of the decorative, marginal elements that accompany the main theme of the picture. In much medieval and Renaissance painting the landscape is subordinate to the principal motif, the mere backdrop to the focal point of the action. The organising force of 'Argument used to be seen in opposition to "by-work" or parergon, the accessory element' (Andrews, 1999:7) and it was Derrida who challenged the conventional assumptions about the marginal status of the 'mere' supplement, emphasising mutual dependency rather than strict hierarchy. Instead, he questions the terms of the opposition, where par is taken to mean 'alongside' or 'against', and ergon is defined as 'work', so 'by-work' is regarded as a reasonable translation of parergon. The terms are deployed in Immanuel Kant's (1790/1992) Critique of Judgement and Derrida (1979:18) maintains that Kant's 'recourse to archaic, scholarly' language (Greek in this instance) is to confer 'something approximating conceptual dignity on the notion of the hors d'ouevre which does not remain simply outside of the work, acting from the sidelines, next to the work (ergon)'. Derrida emphasises that the pargeron, for Kant and philosophical thought generally, is a way of relegating marginal elements and operates against the main work (the ergon). 
The process can be seen in a contemporary account where the term parerga is used in this supplementary sense, in a comment made by Bishop Paolo Giovio (a historian and art collector) in 1527 on the Ferrarese court painter Dosso Dossi, where he states:

The elegant talent of Dosso of Ferrara is proven in his proper works, but most of all in those that are called parerga. For in pursuing with pleasurable labour the delightful diversions of painting, he used to depict jagged rocks, green groves, the firm banks of traversing rivers, the flourishing work of the countryside, the joyful and fervid toil of the peasants, and also the distant prospects of land and sea, fleets, fowling, hunting, and all those sorts of things so agreeable to the eyes in an agreeable and festive manner.

(Giovio in Wood, 1993/2014:64-5)

In the passage a clear distinction is drawn between 'proper' painting, which we can assume would refer to portraits, historical and religious subjects, and those diversionary elements indulged in simply for pleasure.

It is striking that landscape painting had a somewhat 'deferred development' in the West, and that in other parts of the world (as in China, for example) 'landscape painting was an advanced art by the time of the Dark Ages in Europe' (Casey, 2002:5). The question of why it took so long for an independent landscape tradition to emerge is a complex question to answer, not least since many medieval and Renaissance artists could certainly depict landscapes exceptionally well. The promotion of landscape from periphery to centre was accomplished initially by giving landscape a 'name, and thus an invisible and virtual frame' and then 'by sealing it off from texts and other pictures with a physical frame' (Wood, 1993/2014:51). In Derrida the ambition is to demonstrate how porous the boundaries are between the ergon (the 'work') and parergon (the 'by-work'), and he draws on examples in Kant (1790/1992) to indicate how the drapery on near-nude statues, columns on a building and the frames for paintings are transitional elements, troubling what constitutes the 'inside' and 'outside', and are types of pargera (accessory, ornament, decoration).

In a characteristic move Derrida deploys the idea of parergon to deconstruct the theoretical apparatus structuring Kant's argument and he cites such paintings as Lucas Cranach's (1532) Lucretia, depicting a nude woman wearing a transparent veil, to disturb the neat categories Kant tries to impose. Derrida's argument has been helpfully summarised as follows:

In the first instance the ergon is the nude (literally as well as figuratively in the "body") and the drapery is the ornamental extra. But the body as "nude" is partly constituted by the co-presence of the drapery. The nude needs the pargeron drapery to reinforce the sense of nudity; so it is dependent upon, and collaborative with, the so-called ornamental extra, and that ornamental extra loses its status as independent, dispensable supplement.

(Andrews, 1999:7)

Indeed, the supplement is most definitely not incidental, rather it highlights the internal 'lack in the system it augments' (Derrida, 1979:22). The process of signification is radically decentred here, and his method of deconstruction delights in exposing how philosophical 
texts (like Kant's in this example) attempt to suppress the unsettling effects of their own use of language. Such manoeuvres often involve forms of conceptual violence or exclusion, and are tempered by an anxious sense of their own instability, as revealed in his analysis of Kant's distinction between the picture and it's frame, the 'inside' and 'outside' of a work, an opposition that once questioned undermines the entire thrust of Kant's Critique of Judgement.

It was Derrida's contention that both visual and verbal practices never exist in any pure or unmediated form, while an 'otherness' always haunts a work. By illustrating how the parergon pollutes the purity of the ergon he invites us to reconsider the conventionally low status of landscape in art and rethink the significance of the marginal. It complicates the relationship between the inside and outside of an art object, so that the frame becomes the focus of his essay, expanding what we think frames are and what they do. In Wood's (1993/2013:73) account of how the trifling by-work came to trouble the main subject matter he notes how it was the German Renaissance that 'contributed to the broader process of centring the supplement by aggressively converting portions or aspects of the picture that had once been accessory to its purpose, landscape in particular, into the most conspicuous theatres for pictorial ingenuity and inventiveness.'

During the seventeenth century a self-conscious tradition of landscape art and painting became firmly established and was accompanied by generic (paysage in French, paesaggio in Italian) and sub-generic codification, with a system of rules and conventions seeking to aesthetically process the terrestrial environment. The geographer Yi-Fu Tuan has noted how in late sixteenth century England the concept of landscape 'shed its earthbound roots' and 'became fully integrated with the world of make-believe' (cited in Kelsey, 2008:205). Under this singular term lurk two rather different ideas, one of 'domain' and the other of 'scenery', which are encapsulated in Dr. Johnson's classic 1755 dictionary definition of landscape: (1) "A region; the prospect of a country"; (2) "A picture, representing an extent of space, with the various objects in it" (cited in Olwig, 2008:159). It is the play between these meanings that accounts for how landscape works as a cultural practice, as a medium naturalising deep seated political agendas (see also Mitchell, 2002, for an influential discussion of this point).

\section{Dark Visions}

Once this fictional quality of landscape is recognised, it is not difficult to see how the genre could be deployed with such versatility and speak to so many imagined communities. It is this flexible duplicity that is largely responsible for its ensuing durability:

adapted as it was to classical idioms (the paysage historique à la Poussin); the homely rural scene (as in Dutch seventeenth-century art, or in the work of British artists such as Constable and Turner); the Romantic sublime (as in the work of the German Caspar David Friedrich or the British John Martin); the "realist" and regionally specific landscapes of nineteenth-century artists (including those of the Impressionists), and the many varieties of the picturesque purveyed in both elite and mass cultural forms, from grandiose painting to modest lithograph.

(Solomon-Godeau, 2010/2017:108)

The passage gives a sense of the range of ways the world has been portrayed. Of course, it cannot convey all the developments and conventions associated with how we come to view land as a landscape, let alone our place in it, but it does point to when and why certain 
cherished images of 'nature' began to take centre stage. Landscape art, consequently, has been understood as a key site for articulating class relations, a means of forging national identity, a vital mechanism in the exercise of colonial power, and a web of gendered values embedding processes of subjugation (see also Carrabine, 2018c, for further elaboration on these different dynamics).

Representations of landscape convey certain mythologies, as the eco-feminist Carolyn Merchant (1996:43) put it, the "narrative of frontier expansion is a story of male energy subduing female Nature, taming the wild, plowing the land, recreating the garden lost by Eve' and this civilizing mission made 'the land safe for capitalism and commodity production'. More recently Bill McClanahan (2019:2) has drawn on ideas from ecocriticism to enliven a green criminological imagination through an analysis of horror cinema's representations of rural landscapes, urging us to 'recognize what we might think of as ecologies of horror and the horror of ecology'. Many commentators have gone beyond simply regarding landscape as a category of imagery, acknowledging instead that it is a category of perception and a historical force. Here, the landscape genre is subjected to a process of 'reading' in which real and imagined spaces are conceived as 'texts', visual and verbal modes of representation, containing traces of contemporary political and social relations.

The essays in Simon Pugh's (1990) Reading Landscape: Country-City-Capital provide a now classic intervention, which were inspired by the cultural critic Raymond Williams, and explore the passage from rural to metropolitan capitalism in the genre. This re-visioning of landscape is an important step toward a fuller understanding of Piranesi's artistic achievements and innovations. His vast output, which combined with remarkable flights of fantasy, created a new and lasting poetics of representation. The Carceri, or Prisons, are hailed as his most celebrated work today, yet the acclaim is out of all proportion to their modest position within Piranesi's immense oeuvre and they were initially intended as a private work, thought to be of only minor appeal to the young artist's public and rarely purchased. Their first appearance was around 1745, under the title Invenzioni capric di carceri, which were later substantially reworked and republished the fourteen plates with two additional compositions under the title Carceri d'invenzione in 1761, when Piranesi was 41 and at a critical stage in his career.

If seen the Carceri series is seldom forgotten. Figure 1 is one of the menacing images from it, depicting a macabre fantasy structure where carceral space is expanded to the point of dizziness. The sinister subterranean scene deploys a fragmented perspective in which shadowy human figures as well as the viewer's gaze, become lost. The multiplication of staircases, suspended beams, grates, chains, and ropes combined with the haunting presence of silhouettes gives of the impression of an entrapment in hell. It has been said that such 'arresting details' are like the 'focussed moments in a confused dream, confused because there is no narrative to follow, because it is never clear what exactly the figures are doing and because it is not even at all clear what manner of prisons these are' (Penny, 1988:11). A question that immediately arises is where did these nightmare visions come from? One response is to say that the series creatively combines various artistic trends of the eighteenth century. A key influence is a Baroque tradition of theatrical stage design that is largely lost to us now (they have long since crumbled away). Those drawings and designs that have survived are associated with the work of Ferdinando and Francesco Galli, known as Bibiena after their home town, and their family who devised ingenious sets that were widely imitated across Europe from the end of the seventeenth century onwards. Their innovation was to 
produce a scene per angolo (a way of looking at things at an angle) that appeared to deepen the stage and gave quite extravagant illusions of perspective. Ferdinando Bibiena expounded on the principles in his major treatise Architettura Civile, of 1711, which carefully set out how to achieve the dynamism of this new concept, where the traditional centre viewpoint was dispensed with in favour of several diagonal axes, creating rich spatial vistas (see Figure 2) stimulating the vision of spectators.

None of these designers, however, relished the qualities of stone masonry quite as much as Piranesi. In this regard it is worth emphasising that pivotal to understanding Piranesi's 'strange originality lies in his insistence on being styled architeto veneziano' (Wilton-Ely, 1978a:11). Although he remains one of the greatest topographical engravers of all time, his proud and rather eccentrically assumed title of Venetian architect, reveals a lifelong passion for architecture throughout a prolific and varied career. He built very little, yet the lack of practical architectural commissions obliged him to sharpen his skills in etching souvenir views for the flourishing Grand Tour market in Rome. It was in 1740 that he first arrived in the Eternal City, as a twenty year old draftsman attached to the Venetian ambassador, which became his subject and home for the rest of his life - virtually inventing the idea of Rome's 'tragic beauty' (Yourcenar, 1980:88) in over a thousand or so haunting engravings of the city.

Shortly after his first visit to Rome he would memorably write, 'Speaking ruins have filled my spirit with images that accurate drawings could never have succeeded in conveying' (cited in Pinto, 2015:1), which conveys his enthusiasm for the expressive quality of ruins and architectural fantasy. Yet the importance of his Venetian origins and training in architecture and stage design are regarded as the most potent of influences. Especially since Venice, with its many opera houses and theatres offered numerous opportunities for imaginative designers, and its lively traditions of spectacle in state ceremonies, processions and festivals was particularly open to the world of the stage, illusion and fantasy. The city itself was the most densely urban of environments, providing a sensual theatre of architectural experiences and changing perspectives, intensified by varying atmospheric effects of light and colour. In Venetian art there is a long tradition of introspection and subtle awareness of the city's vulnerability that is manifest in the topographical details included in the religious pictures and background settings of early Renaissance portraits. This tradition was given fresh impetus at the time of Piranesi's birth and was one he was later to explore across his work.

\section{Fascinating Ruins}

It is no accident that Venice was the birthplace of the veduta, which translates as 'view', and refers to the faithful representation of an actual urban or rural landscape that is largely topographical in conception. The earliest exponents came from northern Europe, where topography in the art of the cartographer and the painter had been preoccupied with observed fact, stretching back to the fifteenth century. Landscape views and maps were often combined here in diverse and elaborate ways, so that when the Dutch artist Gaspar van Wittel (later famous as Van Vitelli) arrived in Venice around 1697 and painted panoramic views of the city, he was drawing on this tradition while initiating a school of view painting that became a phenomenon in the eighteenth century. Canaletto was the most celebrated practitioner of it and patronage by the 'milordi inglesi' was to make the veduta the most popular contemporary art form (alongside the commemorative portrtait), quickly spreading to other important centres on the peninsula, including Rome, Florence and Naples. His immense success was almost completely dependent on the admiration of wealthy foreign travellers, mostly British, 
for whom the picturesqueness of Venice held a special attraction. These works include the Grand Canal looking West towards the Carità (see Figure 3), which displays his extraordinary ability to render the light, life, buildings, and expanse of Venice in carefully crafted compositions. The semblance of realism and precise observation is highly contrived, requiring considerable skill and using theatrical effects to enliven the scene, compressing a formidable amount of topographical detail into the setting.

The popularity of these images is bound up with the Grand Tour, which was seen in European aristocratic and intellectual circles as a mandatory trip dedicated to completing one's cultural education. It reached a peak in the eighteenth century, becoming a social and socializing form of travel, with an established set of conventions and itinerary. Italy became the preferred destination of wealthy Northern Europeans who came for sojourns lasting months or years, creating a demand for paintings, drawings and etchings to be purchased as souvenirs of their foreign travels. Coinciding with this fashion was a taste for ruins; especially the remains of ancient buildings that were thought to bear witness to a noble past that was irretrievably lost. Thus, a genre developed that sought to represent ideal landscapes in a purely decorative way. These became known as capriccios, or caprice, defined as 'whimsical fantasises', where imaginary elements are added to real landscapes. Giovanni Paolo Panini developed the art form in Rome in paintings such as Roman Capriccio: The Pantheon and Other Monuments (see Figure 4), which collects an array of ancient monuments and deposits them in a fanciful rural setting with scant regard for topographical fidelity. The ruin becomes a fiction, transitioning from margin to centre:

The caprice represents the move of the ruin in painting from the background to the status of subject. We can speak of the poetics of a representation when it has become the subject of invention and thus a work of art unto itself. In the case of the caprice painting, ruined architecture has become the focal point of the artist's invention.

(Augustyn, 2000:433)

The ruin's earlier condition as periphery to, and setting for, the main subject is analogous to the very status of landscape in relation to the religious subjects of painting, as discussed at the beginning of this chapter, where the shifting emphasis on the supplementary, decorative and ornamental cautions against underplaying the significance of its function.

Rome was the city most visited on the Grand Tour and had become the Mecca for travellers by the time Piranesi arrived. Shortly after he was producing vedute and adopting the etched view as a means of securing a livelihood, identifying what would sell in this dynamic market, which in turn became much sought-after mementoes by wealthy foreign visitors. In this initial work 'ruins are shown in their surroundings more or less correctly, without being oversized, later they became huge in comparison with their setting and with the unnaturally dwarfed figures that populate them' (Lehman, 1961:91). Figure 5 is an example anticipating this increasing sense of the histrionic, where the towering ruins of antiquity (in this example it is the remains of an aqueduct system) stand aloof from the mundane activity below, where the inclusion of a clothes-line adds a humorous, yet humbling detail to the scene and is characteristic of his earlier work. It has been said that the "souvenir is the relic secularised, but whereas the relic derives from the corpse, a presence, the souvenir is "dead" experience' (Pugh, 1990:145). There is a sense in which souvenirs, ruins, monuments and emblems 
revived earlier memento mori - mediations on the transience of life on earth - in more secular forms of vanitas.

In Piranesi's etchings of decaying architecture we can see how the scale of this slow destruction informed the extraordinary imagery contained in the Carceri, which blends architectural fantasy with a powerful and unsettling vision of confinement. These are the 'only works in which Piranesi abandons himself to what he called his caprice, or to put it better, to his obsessions and to his hallucinations' (Yourcenar, 1962/1984:105). It seems that his main creative energies were focussed on these capriccios, as a vehicle for architectural experimentation and improvisation, organised around a certain set of themes. Indeed, another reading insists that the compositions reveal 'a highly controlled discipline at work, exploiting the mechanics of baroque illusionism through perspective and lighting to explore new dimensions of architectural expression' (Wilton-Ely, 1978b:72). The penchant for ruins spoke not only to nostalgia, of fallen majesty, but they also have a tragic quality and the sociologist Georg Simmel managed to convey this feeling when he wrote in a 1911 essay on the ruin that 'what strikes us is not, to be sure, that human beings destroy the work of man - this is indeed achieved by nature - but that men let it decay' (Simmel, 1911/1958:380, emphasis in original). What is unsettling is that such 'places, sinking from life, still strike us as settings of a life' and that it is human will that 'has led the building upward'; while 'what gives it its present appearance is the brute, downward-dragging, corroding, crumbling power of nature' (1911/1958:381). The wilderness of nature and how we are all at the mercy of dark forces beyond our control would become crucial to the revival of the Gothic imagination in the late eighteenth and nineteenth centuries. Piranesi's imaginary prisons bear little relation to existing prison buildings or any traditional images of them, but they do herald a new aesthetic combining both terror and power to sublime effect.

\section{Sublime Effects}

As an aesthetic concept, which originated in classical Greece, the sublime was the subject of considerable debate in the eighteenth century, not least since the experience of it was the antithesis of all the values associated with the Age of Reason in which it was so enthusiastically embraced. The concept was most influentially developed by the English thinker Edmund Burke, whose Philosophical Inquiry into the Origin of our Ideas of the Sublime and Beautiful, was originally published in 1757. Although many thinkers had addressed 'the beautiful' by identifying it with classical ideals of harmony, grace and proportion, others thought it eluded a universally comprehensive definition, Burke's unique contribution was to identify 'the sublime' as all-consuming force beyond beauty that that mixes pleasure with pain and fear in all who behold it. Many of the chapter headings in the Inquiry could just as easily be titles for Piranesi's prison drawings: 'Terror', 'Privation', 'Vastness', 'Infinity', 'Difficulty' and so forth. Here there is an attempt to explain why ancient ruins, dark forests, inaccessible castles, dank dungeons and raging thunderstorms (amongst other elemental forces) were becoming attractive to a new artistic and literary sensibility developing in the eighteenth century. The sublime signals the limits of rationality and Burke's Enquiry was the first text to realize and systematize this profound change in aesthetic values.

The re-publication in 1761 of the Carceri involved a substantial reworking of the plates with stronger tonal contrasts, while architectural immensity and spatial ambiguity were further amplified (see Figure 6 for an example). This version is regarded as definitive and was the 
one destined to achieve European influence. The overall tone is more sinister, where vast new structures recede to infinity and exemplify Burke's understanding of the sublime. For some commentators the major thematic change is one veering toward melodrama to achieve this effect:

With few exceptions, the physical horror of prisons was now rendered explicit in terms of their structural immensity and spatial complexity...Also now inserted is a complete repertoire of penal apparatus in the form of chains, cables, gallows and sinisterly indistinct instruments of torture, many of them infused with a sense of decay through endless use. Animating this punitory hell is an increased number of figures, together with certain episodes of punishment being enacted. Although this latter feature already appears once in the original version with plate $\mathrm{X}$ [Figure $1]$, there the group of bound prisoners thrust forward on a cantilevered slab possesses the effect of sculpture in the mode of Michaelangelo's Slaves rather than that of the pathetic huddles of oppressed humanity in the later version of the plates.

(Wilton-Ely, 1978b:85)

Others have noted how a 'suggestion of torment floats in the air of the Prisons' but it is almost always a 'vague' suggestion. As Marguerite Yourcenar (1984:117-8) goes on to write, the 'true horror of the Prisons is less in their few mysterious scenes of torture than in the indifference of these human ants roaming through enormous spaces, whose various groups seem almost never to communicate among themselves or even to take not of their respective presences, and still less to realize that in some dim corner a prisoner is being tortured'. For me the crucial question, and one which ties visual and narrative criminologies, is why did he call these spectacular architectural hallucinations Prisons?

Already in Piranesi's time the later Carceri images spoke to fresh themes and offered striking visual analogies of disturbing experiences. They are certainly among the first and most enigmatic indications of the obsession with torture and incarceration that comes increasingly to the fore in the last decades of the eighteenth century. Horace Walpole saw them as "chaotic and incoherent scenes where death sneers in the darkness" (cited in Yourcenar, 1962/1984:125) and these dark images appear in his novel The Castle of Otranto, published in 1764 and set in an imaginary Italian dungeon. Likewise, William Beckford's novel Vathek, published in 1786, traces a disturbing journey through vast subterranean halls that are strongly influenced by Piranesi's Prisons. Both Walpole and Beckford are regarded as pioneers of the gothic novel, while allusions to Piranesi feature prominently in Victor Hugo, and the image of confinement is a metaphor put to a wide range of uses in literary sensibility. Such settings reveal much about the structuring principles of the Romantic imagination, and the tensions betrayed in the appeal of raw despotic power. Fictional metaphors and social critique are interwoven:

arbitrary arrests (lettres de cachet) and the state prisons of the Ancien Regime, the symbolism of the Bastille and of its epic fall, the revolutionary jails, the political detentions throughout Metternich's Europe...the police repressions of popular uprisings - all conspired to dramatize and poeticize the prison image... The eighteenth century is known to be the age of "reason"; but it is also especially as the century came to a close - an age that delighted in horror, and was fascinated by all the manifestations of coercion. The obsession with walls, 
crypts, forced religious vocations, inquisitorial procedures, parallels the beginnings of a revolt against arbitrariness.

(Brombert, 1978.:7-8)

I have argued elsewhere (Carrabine, 2012) that this fascination with horror could very easily fall into hammy melodrama (a tone wonderfully sent up in Jane Austen's Northanger Abbey, written in the 1790s), but the creeping unease generated by Franz Kafka's modernist fiction is hugely indebted to the Gothic. In his novels The Trial (1914) and The Castle (1922) and shorter stories like "Before the Law", "In the Penal Colony" and "The Metamorphosis" they each take up the theme of an innocent victim caught up in relentless machinations well beyond their control.

From Josef K's arrest for a nameless crime in The Trial (with no hope of acquittal) to Gregor Samsa's grotesque metamorphosis (into a giant insect) Kafka's stories explore the question of confinement with immensely unsettling results. In the latter story the horror derives not so much from the description of the bizarre transformation, but the indifferent way his family react to the event, suggesting that the tale is really 'about our acquiescence in the face of the evil that surrounds us' (Eco, 2007:323). The theme of confinement and doomed flights from imprisonment are crucial Gothic conventions, yet for Burke the pleasures deriving from horror arise when we are at a safe distance from the causes of fear. Otherwise the experience would be simply terrifying.

\section{Conclusion}

To return to the question why Piranesi called these nightmare fantasies Prisons, one answer is to look forward and see how they have had such a grim resonance on our own times. Another response is to look backwards and explore a concept which has especially preoccupied the Italian imagination and that is visions of the Last Judgement, of Hell, and the descent into Dante's inferno. So, a fruitful line of enquiry would be to explore the ties between Piranesi's 'entirely secular Prisons and the old sacred conceptions of an Immanent Justice' (Youcenar, 1984:120) in medieval other worlds. I want to finish then with some thoughts on where the approach outlined here might lead. Some time ago Foucault criticized historians for what he called their 'impoverished idea of the real' (cited in Burke, 2008:64), as they left no space for what is imagined. French historians have since responded to this accusation in significant ways.

One example is Jacques Le Goff's (1981/1984) The Birth of Purgatory, which traces the origins of the idea of a netherworld in the Middle Ages by connecting it to changing conceptions of space and time. He argued that the idea of a 'third place' in the afterlife, along with heaven and hell, came into full bloom as a formal Catholic belief and doctrine rather late - in the twelfth century. It was gradually established as an intermediate space in which some lost souls were subjected to a trial that could be reduced through the prayers of perishable mortals. A distinct geography of the other world took shape in a detailed theology of retribution, sacrifice, penalties, pardons, and spiritual exchange between the living and the dead. Le Goff was also one of the first scholars to examine the history of dreams, so that studies of visions, ghosts and the supernatural have become central to the new concern in cultural history with the active role of the imagination. Such studies have explored 'apparitions of the ordinary dead, of everyday ghosts' and those occasions when the departed might return from the grave (Schmitt, 1994/1999:2). 
My overall point then is that Piranesi's images have offered powerful metaphors for understanding social relations, and that the methods of both narrative and visual criminology can draw on studies in the history of representation, whether these be literary, visual or mental that have flourished in recent decades and from which critical counter-languages can emerge. In this regard, Derrida's method of deconstruction where the strategy is to focus on a repressed theme, pursue its textual traces and indicate how they subvert the apparatus striving to hold them in place. By challenging conventional assumptions his approach can be characterized as critical (rather than purely nihilistic, as his detractors maintain), so that when he addresses the systems of painting and language, he describes the 'parasitizing' of systems, their flowing into one another and how they create a 'partition of the edge' (Derrida, 1987:7). He plays on this inside and outside of a work through a consideration of the transitional position of the frame and the idea of a supplement, as we saw earlier in this chapter, opening up new ways of thinking about them.

In Derrida all texts are a 'play of presence and absence, a place of the effaced trace' (Spivak, 1976:lvii) and he deliberately deploys a strategy of re-contextualizing concepts by moving them from one system or discipline to another. Later he would introduce the idea of 'haunting into the very construction of a concept' (Derrida, 1994:161) in a book preoccupied with the 'death' of communism and how Marxism would continue to haunt capitalist societies long after its supposed demise. His concept of 'hauntology' is a pun on the more traditional concept of ontology, the philosophical study of what can be said to exist. Yet it brings into focus the question of time 'in a way that had not quite been the case with the trace or différance' and is more than an 'attempt to revive the supernatural' or 'just a figure of speech' (Fisher, 2014:18). Instead, it is a crucial addition to the project of deconstruction and can help enlarge our understanding of the real, the symbolic and the imaginary. Piranesi's Prisons pitch us straight into extraordinary landscapes and the aim of this chapter has been to mobilize some conceptual resources to engage with them.

\section{Acknowledgements}

An earlier version of this paper was presented at the 2017 American Society of Criminology conference in Philadelphia and a later one at the 2018 British Crime Historians symposium held at Edge Hill University, and I would like to offer my thanks to all those who offered comment. This work was supported by a Leverhulme Trust Major Research Fellowship, MRF-2014-052.

\section{References}

Alpers, S. (1983) The Arts of Describing: Dutch Art in the Seventeenth Century, London: Penguin.

Alper, S. (1983/1995) 'Interpretation without Representation, or, The Viewing of Las Meninas' in Fernie, E. (ed.) Art History and its Methods: A Critical Anthology, London: Phaidon. Pp.281-290.

Andrews, M. (1999) Landscape and Western Art, Oxford: Oxford University Press. Augustyn, J. (2000) 'Subjectivity in the Fictional Ruin: The Caprice Genre', in The Romantic Review, 91(4):433-457.

Bal, M. (1991) Reading Rembrandt: Beyond the Word-Image Opposition. Cambridge: Cambridge University Press. 
Brombert, V. (1978) The Romantic Prison, Princeton: Princeton University Press.

Bryson, N. (1981) Word and Image: French Painting of the Ancien Régime, Cambridge:

Cambridge University Press.

Bryson, N. (1988) 'Introduction.' In N. Bryson (Ed.), Calligram: Essays in New Art History from France (pp. xiii-xxix). Cambridge: Cambridge University Press.

Burke, p. (2008) What is Cultural History? Cambridge: Polity.

Brown, M. and E. Carrabine (eds.) (2017) The Routledge International Handbook of Visual Criminology, London: Routledge.

Carrabine, E. (2012) 'Telling Prison Stories: The Spectacle of Punishment and the

Criminological Imagination', in Cheliotis, L (ed.) The Arts of Imprisonment: Essays on

Control, Resistance and Empowerment, Dartmouth, Ashgate.pp.47-72.

Carrabine, E. (2016) 'Picture This: Criminology, Image and Narrative', in Crime, Media,

Culture, 12(2):253-270.

Carrabine, E. (2018a) 'Punishment in the Frame: Rethinking the History and Sociology of

Art', The Sociological Review, 66(3):559-576.

Carrabine, E. (2018b) 'Reading a "Titian": Visual Methods and the Limits of Interpretation', in Deviant Behavior, 39(4):525-538.

Carrabine, E. (2018c) 'Geographies of Landscape: Representation, Power and Meaning', in Theoretical Criminology, 22(3):445-467.

Casey, E. S. (2002) Representing Place: Landscape Painting \& Maps, Minneapolis:

University of Minnesota Press.

Derrida, J. (1979) 'The Parergon', in October, Vol. 9, Summer, pp-3-41.

Derrida, J. (1987) The Truth in Painting, Chicago: University of Chicago Press.

Derrida, J. (1994) Specters of Marx: The State of the Debt, the Work of Mourning, \& the New International, London: Routledge.

Eco, U. (2007), On Ugliness. London: Harvill Secker.

Fisher, M. (2014) Ghosts of My Life: Writings on Depression, Hauntology and Lost Futures, Hants: Zero Books.

Greslé, Y. (2006) 'Foucault's Las Meninas and Art-Historical Methods', in Journal of

Literary Studies, 22(3/4):211-228.

Foucault, M. (1966/2002) The Order of Things, London: Routledge.

Kant, I. (1790/1992) Critique of Judgement, Oxford: Oxford University Press.

Kelsey, R. (2008) 'Landscape as not Belonging', in DeLue, R. and J. Elkins (eds.) Landscape

Theory, London: Routledge.pp. 203-213.

Lehman, K. (1961) 'Piranesi as Interpreter of Roman Architecture', in Parks, R. (ed.)

Piranesi, Northampton, Mass: Smith College Museum of Art., pp.88-98.

Le Goff, J. (1984) The Birth of Purgatory, London: Scolar Press.

McClanahan, B. (2019) 'Earth-World-Planet: Rural Ecologies of Horror and Dark Green

Criminology', in Theoretical Criminology. https://doi.org/10.1177/1362480618819813.

Merchant, C. (1996) Earthcare: Women and the Environment, London: Routledge.

Mitchell, W.J.T. (2002) 'Imperial Landscape', in Mitchell, W.J.T. (ed.) Landscape and

Power, Chicago: University of Chicago Press.pp.5-34. $2^{\text {nd }}$ edition.

Mitchell, W. .J. T. (2015) Image Science: Iconology, Visual Culture, and Media Aesthetics.

Chicago: University of Chicago Press.

Olwig, K. (2008) 'The "Actual Landscape," or Actual Landscapes', in DeLue, R. and J.

Elkins (eds.) Landscape Theory, London: Routledge.pp. 158-177.

Penny, N. (1988) Piranesi, London: Bloomsbury.

Pinto, J. (2015) Speaking Ruins: Piranesi, Architects, and Antiquity in Eighteenth-Century

Rome, Ann Arbor: University of Michigan Press. 
Pugh, S. (1990) 'Loitering with Intent: From Arcadia to the Arcades', in Pugh, S. (ed.) Reading Landscape: Country-City-Capital, Manchester: Manchester University Press.pp.145-160.

Pugh, S. (ed.) (1990) Reading Landscape: Country-City-Capital, Manchester: Manchester University Press.

Schmitt, J-C. (1994/1999) Ghosts in the Middle Ages: The Living And The Dead In Medieval Society, Chicago: University of Chicago Press.

Simmel, G. (1911/1958) 'Two Essays: "The Handle" and "The Ruin"”, in The Hudson Review, 11(3):371-385.

Solomon-Godeau, A. (2010/2017) 'Framing Landscape Photography', in Parsons, S. (ed.) Photography after Photography: Gender, Genre, History, Durham: Duke University Press. Pp.107-122.

Spivak, G.C. (1976) 'Preface', in Derrida, J. (1976) Of Grammatology, Baltimore: John Hopkins University Press. Pp. ix-lxxxvii.

Wilton-Ely, J. (1978a) Piranesi, London: Lund Humpries.

Wilton-Ely, J. (1978b) The Mind and Art of Giovanni Battista Piranesi, London: Thames and Hudson.

Wilton-Ely, J. (1993) Piranesi as Architect and Designer, New Haven, CT: Yale University Press.

Wood, C. (1993/2014) Albrecht Altdorfer and the Origins of Landscape, London: Reaktion. $2^{\text {nd }}$ ed.

Yourcenar, M. (1962/1984) The Dark Brain of Piranesi and Other Essays, Oxon.: Aiden Ellis. 
Figure 1 Giovanni Battista Piranesi, Carceri, pl X, First State, c.1745.

Image to be supplied separately.

Source: (C) The Trustees of the British Museum.

Figure 2 Ferdinando Galli de Bibiena, Illustration of a Scene Design from Direzioni della Prospettiva Teorica, c. 1711.

Image to be supplied separately.

Source: McNay Art Museum/Art Resource, NY. (C) Photo SCALA, Florence.

Figure 3 Canaletto, The Mouth of the Grand Canal looking West towards the Carità, c.17291730 .

Image to be supplied separately.

Source: Royal Collection Trust/@ Her Majesty Queen Elizabeth II 2019.

Figure 4 Giovanni Paolo Panini, Roman Capriccio: The Pantheon and Other Monuments, 1735 .

Image to be supplied separately.

Source: (C) Indianapolis Museum of Art.

Figure 5 Giovanni Battista Piranesi, Vedute di Roma: the Fontana dell' Acqua Giulia, c.1753. Image to be supplied separately.

Source: (C) National Galleries of Scotland.

Figure 6 Giovanni Battista Piranesi, Carceri, pl XIII, Second State, c.1761.

Image to be supplied separately.

Source: (C) The Trustees of the British Museum. 